This item was submitted to Loughborough's Research Repository by the author.

Items in Figshare are protected by copyright, with all rights reserved, unless otherwise indicated.

\title{
Performativity and performance
}

PLEASE CITE THE PUBLISHED VERSION

http://dx.doi.org//10.1093/oxfordhb/9780199328581.013.30

PUBLISHER

Oxford University Press

VERSION

AM (Accepted Manuscript)

LICENCE

CC BY-NC-ND 4.0

REPOSITORY RECORD

Lloyd, Moya S.. 2019. "Performativity and Performance". figshare. https://hdl.handle.net/2134/17497. 


\title{
Chapter 29
}

\section{Performativity and performance}

\author{
Moya Lloyd \\ Loughborough University
}

\begin{abstract}
This article explores the concepts of performativity and performance in feminist theory. It begins by examining the idea of gender performativity in the work of Judith Butler, tracing its development from her earliest writings through to Gender Trouble and Bodies that Matter, and showing how Butler's initial argument draws from phenomenology, and from performance studies (where acts are understood in theatrical terms). This is followed by a discussion of gender understood ethnomethodologically as a type of routine performance or form of "doing". The second half of the article focuses on linguistic theories of performativity, derived from J. L. Austin and Jacques Derrida, and how they have been used by feminists such as Catharine MacKinnon, Rae Langton, and Judith Butler to illustrate pornography and hate-speech. After a discussion of the performativity of pornography, the focus turns to citationality, resignification, and "talking-back".
\end{abstract}

Keywords: gender performativity, linguistic performativity, gender as “doing”, gender performance, ethnomethodology, theatrical acts, pornography, hate-speech, "talking-back".

In 1990 a book was published that changed feminist theory profoundly. The book was Gender Trouble and its author was Judith Butler. The transformations it wrought on feminist understandings of the relationship between sex and gender centered on the effect of one of its central concepts. The concept in question was performativity, or, more accurately, gender performativity, for performativity has a history that predates and exceeds the work of Butler. 
It originates initially in speech act theory; specifically, in the work of English philosopher, J. L. Austin where it is used to denote a specific kind of linguistic utterance: words that "do" things (1962). It is this notion that words could do things - that communication is a type of action - that was to prove hugely influential both within and outside of feminism, giving rise to one of the main fault-lines dividing current theories of performativity, namely that between those who treat performativity as a formal quality of language and those who construe it as a social, cultural, or corporeal practice. ${ }^{1}$ In what follows, we will see examples of both strands of thinking at work in feminist theory.

Performativity is not the only analytical frame relevant to this article. The metaphor of performance has also been used widely to understand gender. There are at least two main, sometimes interrelated, traditions of performance theory that are relevant to feminist thinking. The first derives from performance studies, broadly conceived, and understands "acts" in dramatic or theatrical terms. The other found in (feminist) sociology, conceives of gender ethnomethodologically as a "performance or accomplishment achieved in everyday life" (Brickell 2003: 159). While there is some overlap in vocabulary, with for instance performance studies using "performative" as an adjective for "performance", and the theory of gender performativity referencing gender "performances", conceptually performance and performativity tend to connote different things, have distinct theoretical origins, and have diverse implications in relation to gender.

This article will divide broadly into two parts. In the first, I examine how performativity and performance have been used to understand gender. In the second part, I focus on what might be termed linguistic performativity, and how it has been taken up within feminism to understand pornography and hate-speech. Since Gender Trouble is the pivotal text in feminist discussions of gender performativity, this is where I will begin. Of necessity, this exploration will require us to examine some of Butler's earlier writings where the traces 
of an alternative configuration of the performativity-performance nexus may be discerned. For although Butler is best known for her philosophically-grounded understanding of performativity in Gender Trouble and beyond, her first forays into the field drew from feminist phenomenology and performance studies.

\section{Gender performativity}

A common characteristic of Anglo-speaking feminism throughout the 1970s and 1980s was the effort to differentiate between sex and gender. As one classic formulation contended: “"[s]ex' is a biological term", connoting "the differences between individuals that make them male and female", while “"gender' is a psychological and cultural one” referencing the features ascribed to men and women (Oakley, 2005 [1972]: 7). From this perspective sex was regarded as the fixed biological bedrock upon which culturally variable gender, masculinity and femininity, was constructed. Feminists drew attention to the category of gender not in order to do away with or to replace the category of sex (see Nicholson 1994); rather they stressed the distinction between sex and gender in order to challenge both biological determinism, the idea that the differences between men and women are natural and cannot be changed, and the sexism they saw following from that position. Their diverse understandings of the relation between sex and gender aside, they proposed that the constructed nature of gender renders it contestable and, perhaps even, ultimately eliminable. Few of these feminists challenged, in fact most of them took for granted, the naturalness of sex. Indeed, many regarded the sexed body as the factor that united all women.

In Gender Trouble Butler interrogates this relation between sex and gender, and, in particular, seeks to show that sex is just as constructed as gender. Radically and controversially, in fact, Butler rejects the assumption that sexual difference is the foundation upon which gender is erected. Building on arguments derived from, amongst others Michel 
Foucault (1978), Adrienne Rich (1980), and Monique Wittig (1981), she conceptualizes gender as the "apparatus" that produces sexual difference (Butler 1990a: 7). ${ }^{2}$ It is in the context of her discussion of how subjects acquire gendered identities within the terms of what she calls the "heterosexual matrix" (1990: 34), or the "law of heterosexual coherence" (1990: 138), now generally described as heteronormativity, that Butler deploys the idea of performativity.

The concept of performativity, as noted, originally stems from the speech act theory of J. L. Austin. A revised and influential version is also developed by Jacques Derrida (1988 [1972]), whose idea of performativity as a quality of language emerges out of his critical reading of Austin. Although Butler will eventually draw explicitly from Derrida, as well as engage with Austin, the idea of gender performativity has rather different beginnings. It arises initially out of Butler's changing assessments of Simone de Beauvoir's idea that “One is not born, but rather becomes, a woman" (1983 [1949], p. 295; see Butler 1986a, 1986b, 1988, 1989a; see Lloyd 2007), and so is part of Butler's exploration of what she terms, in an article prior to the publication of Gender Trouble, a "politics of performative gender acts" (1988: 530).

Two claims of Beauvoir's that Butler focuses on in these writings are relevant to our discussion. The first is that the body is not a "natural fact" but an "historical idea" that only gains meaning from being "signified within an historically specific discourse". Butler reads this as implying that gender is an idea that the body assumes "as if it were its natural form" (1989: 254, my emphasis). We might see in this reading of Beauvoir the first stirrings of Butler's own view that sex is gendered. The second is the claim that one becomes a woman. It is in the process of investigating what this involves that Butler's notion of gender performativity begins to take shape. 
According to Butler, for Beauvoir gender is not "only a cultural construction imposed upon identity," but to "become" a woman is also "a process of constructing ourselves". Butler parses this as meaning that becoming a woman entails "a purposive and appropriative set of acts" leading to the assumption of a "certain corporeal style" (1986: 36). Or, as she puts it in a later piece, in words she will later use to describe her own theory, for Beauvoir gender is "an identity instituted through a stylized repetition of acts" (1988: 519, original emphasis; see Butler 1990: 140). Additionally, although the idea of self-construction might appear to imply both that we can shape our genders in any way we like and that we can become any gender we want, actually this is not the case since, Butler notes, Beauvoir never envisaged any genders "beside 'man' and 'woman"'. To Butler this suggests that Beauvoir understands gender as limited by the binary system men/women, a system that is an historical construct not an "ontological necessity" (1986: 47). It is within the terms of this gender system that certain persons become women, a process that involves "interpreting a cultural reality laden with sanctions, taboos, and prescriptions" (Butler 1986: 40), a view Butler will later recast as a process of engagement with constraining gender norms, although she does not yet describe this mode of "enacting and re-enacting received gender norms" as performative (1986: 48).

The issue that concerns Butler is how Beauvoir conceives of "acts". Butler takes Beauvoir to be adopting and recasting "the doctrine of constituting acts from the phenomenological tradition" (1988: 519). The problem with this tradition, Butler alleges, is that it relies on individualist assumptions since it focuses on the particular subject enacting becoming - their gender. From a feminist perspective, Butler charges, this approach risks overlooking the systemic nature of women's oppression and neglecting the collective dimensions of gendered performances. To redress this deficiency, therefore, Butler turns to an alternative tradition of acts, "acting in the theatrical sense" (1988: 519) or performance. 
Within the context of a theatrical performance, the staging of a play for example, "acts" are a shared, collective experience encompassing actors and audience; actors embody roles that are scripted and rehearsed; although scripts might be enacted in different ways by different actors, nevertheless those enactments are always constrained to some degree by the terms of the script. Butler suggests thinking of gender as an act in this way. To consolidate her argument, she consults the work of social anthropologist Victor Turner. Butler derives from Turner the idea that human life as ritual social drama depends on the repetition of social performances, a repetition that is simultaneously "a reenactment and re-experiencing of a set of meanings already socially established," but one that also secures their legitimation (1988: 526). Butler conjectures that the same is true of gender; it too is a "ritualized, public performance" (Butler 1988: 526n.9, my emphasis), and not, as is often assumed, an individual expression of an inner gender identity. The effect of gender is produced by the repetition of particular bodily gestures, activities and movements, and these repeated gender performances are the mechanisms whereby the dualistic, heteronormative (or presumptively heterosexual) structure of sex and gender is perpetuated, and an individual gender identity created.

Butler, at this stage, tethers her account of gender performativity to performance theory rather than to the linguistic philosophy of either Austin or Derrida (see also Loxley, 2007). ${ }^{3}$ When she suggests that gender reality is performative, "real only to the extent that it is performed" (Butler, 1988: 527), she is contending that gender is "real" only insofar as it is sustained through repeated social performances understood theatrically or dramaturgically. ${ }^{4}$ By the time that Gender Trouble appears, however, Butler's work has undergone a number of important modifications that bear on her discussion of gender performativity. Little remains of her initial reading of Beauvoir as some kind of performative theorist avant la lettre; all explicit references to a phenomenological theory of constituting acts have disappeared from 
the text; and the only direct reference to Turner is hidden in a footnote (Butler 1990: 169 n.71). ${ }^{5}$ Instead, much of the language used in her earlier discussion and many of the key assertions are now presented as features of Butler's own account of gender performativity: that, for example, gender is a form of "ritual social drama" (Butler 1990: 140; see also 1988: 526); that gender identity is an effect of the "stylized repetition of acts" rather than the expression of an inner core (Butler, 1990: 140); that such acts are fundamentally somatic; and that it is the repetition of these acts that maintain compulsory heterosexuality. Nevertheless, there are some important changes.

The essence of Butler's account of performativity in Gender Trouble is her claim that "gender is always a doing, though not a doing by a subject who might be said to pre-exist the deed". Indeed, she writes a little further on, "[t]here is no gender identity behind the expressions of gender; that identity is performatively constituted by the very 'expressions' that are said to be its result" (1990: 25). Instead of Turner or Beauvoir, Butler now iterates this notion by way of Nietzsche, specifically his claim in On the Genealogy of Morals that "there is no 'being' behind doing, effecting, becoming" (cited in Butler, 1990: 25). Gender is performative, for Butler, in that it only exists in the "doing", in the replication of the corporeal repertoire (actions, gestures, movements) that renders one masculine or feminine. This notion of gender performativity also has radical implications for how the subject is understood. Butler jettisons the conception of an autonomous agent able to implement his/her goals and projects at will; instead it is the repeated doing of fleshly acts that constitutes the gendered subject as a gendered subject. In other words, for Butler, doing gender is not performed by an already fully-fledged gendered subject who consciously directs his/her own activities. It is the means by which a gendered subject is produced.

The anti-essentialist account of subjectivity that follows from apprehending gender as performative also has implications for how agency is theorized. For Butler, it too inheres in 
the repetitions constituting the gendered subject, repetitions that generate the illusion of a stable gender identity. Calling on Esther Newton's anthropological study of female impersonators, Mother Camp (1972), Butler proposes that gender shares the same imitative structure as drag. All gender performances, she suggests, masculine or feminine, gay or straight, are a form of impersonation. It is just that some appear to be natural, namely those where sex, gender, and desire converge in the way determined by compulsory heterosexuality; that is, where masculinity follows from a male body, and femininity from a female body, and where both issue in sexual desire for the opposite sex and gender. They appear that way because, by repeating specific gestures, actions, and movements they reproduce a rough approximation of what idealized heterosexual gender is supposed to look like. By somehow exposing the artificiality of gender, as the drag artist does in "his" parody of femininity, it is possible to disclose the performative or constituted nature of gender. This is why in Gender Trouble Butler argues that "the task is not whether to repeat" the practices constitutive of gender; it is "how to repeat" so that "through a radical proliferation of gender" it is possible to "displace the very gender norms that enable the repetition itself" (1990: 148, first emphasis mine; second in the original).

Critics came out in force in response to Butler's arguments. Some took her to be advocating a volitional politics (Rothenberg and Valente 1997), often centered on the idea drawn from her discussion of drag and parody that, as Elspeth Probyn puts it, "we can have any whatever type of gender we want" and that "we wear our genders as drag" (1995: 79; see also Martin 1992; and Hawkes 1995). They read her, in other words, as suggesting that the individual performs gender in the same way that an actor takes on a role on the stage. Others, by contrast, took the opposite tack. They believed that the theory of gender performativity entailed a mode of determinism that meant subjects were inextricably caught in power relations they were unable to resist or transform (Weir 1996). These reservations about the 
conception of agency that gender performativity apparently entailed also led to concerns about the view of the subject it seemed to imply (Benhabib 1995; Assiter 1996).

In Bodies that Matter (1993), Butler revisits the question of how political action to undermine gender norms is doable even when there is no "“doer' behind the deed" (Butler, 1990, p. 25). To do so she explicitly reorients her understanding of performativity by way of Derrida's discussion of Austin. In contrast to the language-based forms championed by Austin and Derrida, Butler's original innovation in relation to performativity was to see it as a form of bodily enactment or style of the flesh, that is, as non-verbal (see Walker 2003). This was, as observed, an understanding of performativity partially indebted to a theatrical conception of acts. From Bodies that Matter, however, Butler's account of performativity shifts course. It is now increasingly presented in linguistic terms.

In "Signature Event Context” (1988 [1972]), Derrida takes issue with certain features of Austin's account. After setting out the general conditions for successful, or what Austin refers to as "happy," performatives in How to Do Things with Words (1962), he then sketches a distinction between serious and non-serious uses of language. It is this distinction that troubles Derrida. Non-serious uses, for Austin, include words pronounced by an actor on a stage, for instance, or "in soliloquy" (1962: 22). Austin describes these words as "hollow or void", as "parasitic upon" ordinary speech, and as "etiolations of language" (1962: 22, original emphases). Derrida demurs: he sees them as no different from ordinary speech. Any performative utterance whether on stage or in life, succeeds, he contends in contrast, only by repeating "a "coded" or iterable utterance" (1988 [1972]: 18). Its success depends, in other words, on its being a citation.

Taking her lead from Derrida, Butler proposes that sex and gender are both similarly citational. She thus writes, for example, that "the norm of sex only takes hold to the extent that it is 'cited"” (1993: 13), as when for instance a doctor announces a child's sex at its birth 
(1993a: 7); and that femininity is the effect of "the forcible citation of a norm" (1993a: 232), such that behavior is identifiable as feminine precisely because it reiterates - cites - the fleshly styles (acts, gestures, movements) that historically have come to signify femininity (wearing make-up, sitting with crossed legs, or, in a different cultural context, wearing a veil).

There is one particular consequence for Butler's argument of this turn to Derrida that is noteworthy in the light of her earlier work. It concerns the rejection of any linguistic distinction between "real life" and "the stage", both of which for Derrida contra Austin rest on the same structure of citationality, a position Butler also accepts. The move to understanding "performativity as citationality", as Butler now labels her discussion of performativity (1993), has particular implications for its theatricality. She returns to the idea of an "act" to explain. Acts, understood from the perspective of performativity are not "singular", "deliberate", or freely chosen, and as such cannot be "simply equated with performance" understood dramaturgically (Butler 1993: 13, 225, 94). The "actions" constitutive of gender are, by contrast, reiterative actions, repetitive actions, actions that “echo[...] prior actions" (Butler 1993: 227). Moreover, they are compulsory, enforced actions, involving "regularized and constrained repetition", and "embodying" of gender norms (Butler 1993: 95, 231). She continues that it is "in relation to such a compulsory citationality that the theatricality of gender is also to be explained" (Butler 1993: 232, my emphasis). It is not that all gender is dramaturgical or staged; it is not a role put on and taken off by a pre-existing self or actor. A citation will appear to be theatrical, she now asserts, to the degree that it "mimes and renders hyperbolic the discursive convention" by which it is governed (Butler 1993: 232, original emphasis), whether through a "hyperbolic "performance"” of death in ACT UP “die-ins", or by a "hyperbolic display" of femininity at a drag ball or AIDS benefit (Butler 1993: 233). 
Such hyperbolic gestures are important, for Butler, not only in terms of her exploration of the relation between performativity and theatricality; they are also important in respect of the possibilities for agential change. They offer an opportunity, she suggests, to work "the weakness in the norm" (1993: 237); that is, to contest the terms of heteronormativity. Butler invokes a second aspect of Derrida's argument here: that no sign is ever tied indelibly to any particular context but always has the capacity to split from one situation to be reiterated in any number of others, such that its meaning shifts in the process. Gender norms, Butler proposes, may be similarly "decontextualized" and resignified or reworked. Agency, for Butler, is thus not an inborn property of the individual. It is a possibility integral to the performative practice of citation that supports and maintains the regulatory force of gender norms. The critical potential of drag, though nothing can be guaranteed, rests on its ability to challenge the taken-for-granted nature of heterosexual performativity by demonstrating that "heterosexual regimes" are unable to "contain their own ideals" (Butler 1993: 237), as when at its most simple a (gay or straight) male "does" femininity.

While Butler is widely credited with introducing the idea that gender is a form of "doing", and that gender might be conceptualized as a "performance", in fact, she is not the first to make these claims. In the next section, therefore, I examine the work of three thinkers whose work, although certainly theoretically distinct from Butler's, nevertheless anticipates it in a number of important ways.

\section{Gender as performance, gender as "doing"}

According to Greg Smith (2011: 125), the first person to introduce the concept of social performance to sociology was Erving Goffman $(1959,1976)$. His ethnomethodological account was to have a significant influence in sociology in general, but also on the 
development of feminist sociology specifically (see West 1996; Deegan 2014). In The Presentation of Self in Everyday Life, drawing on the metaphor of a theatrical performance ("life as theatre"), Goffman explores the ways in which social interactions are structured, concentrating on the "enacted and displayed aspects of our everyday "performances"” (Smith 2011: 137). The gist of Goffman's argument is that the self is an effect of their "performances" to others. During the course of social interactions, "interactants" will endeavor to manage their "impressions" so as to create the right effect on their "audience". To convey what he means by this, Goffman talks of the "scripts" the actors use, of "belief in the part one is playing" (1959: 28), of "dramatic realization" - the capacity to "express ...what he wishes to convey" (1959: 40), of setting, "scenery" and "stage props" (1959: 32), and so forth.

What concerns Goffman is not those "aspects of theatre that creep into everyday life" but "the structure of social encounters" (1959: 246). Although the individual is certainly able, to some degree, to "manage" the impressions s/he is attempting to create by manipulating elements of the performance, by for example donning garb that makes the performance of a particular role more convincing, or by ensuring that they move in the "right" way, nevertheless they do not have full freedom to act. Individuals are not able to stage performances just as they wish or to define situations in any way they please; rather social conventions - or what he later called "frames" (Goffman 1974) - exist within which those individual performances take place, including, for instance, "shared vocabularies of body idiom" (Goffman 1963: 35; see also Lloyd, 1999: 119-21; Brickell 2003: 160; Smith 2011: $138 \mathrm{ff}$.$) .$

Although Goffman did not address questions of gender directly in The Presentation of Self in Everyday Life, he does in later work, where, he posits what appears to be a social constructionist - or anti-essentialist - account of sex and gender. So, he argues for instance 
that arrangements between the sexes that seem to be an effect of natural biological differences between them - he uses segregated toilet facilities as an example - are, in fact, ways of "producing" sex difference (Goffman 1977: 316) and that the placement of all infants into one or other "sex class" may be characterized as a form of sociological "sorting" (Goffman 1977: 302-3). Goffman characterizes gender as a "behavioral style", "stylization", "ritual-like" display, and as a mode of enactment (1976). At times, the language used, together with his repudiation of the idea that there is an "underlying reality" to gender, or anything that "lies behind or underneath" expressions of femininity or masculinity (1976: 77) - is eerily resonant of Butler's later theory of gender performativity. At other points, however, Goffman's argument is clearly moving in a different direction to Butler's, as for example when he talks of the "apparent optionality" (1976: 71) of gender displays or performances, a position that has the effect, according to one set of scholars, of "segregating gender display from the serious business of interaction" and of obscuring the ways that gender is an "ongoing activity embodied in everyday interaction" (West and Zimmerman 1987: 130).

It is to the account developed by Candace West and Don Zimmerman (1987), the scholars just alluded to, that I now want to turn. Dissatisfied with standard theorizations of the sex-gender relationship, in "Doing Gender" West and Zimmerman develop what they refer to as an "ethnomethodologically informed ... understanding of gender as a routine, methodical and recurring accomplishment" (1987: 126); gender as a form of interactional or social "doing". 6 Their thesis rests not on the standard dualistic sex/gender division familiar from feminism, but on a tripartite classification that differentiates between "sex", understood as "a determination made through the application of socially agreed upon biological criteria for classifying persons as females or males" (for example, chromosomes or genitalia); "sex category" which is "established and sustained by the socially required identificatory displays 
that proclaim one's membership in one or the other category" but which allows for membership to be claimed in one sex category when the "sex criteria" are lacking (where a male might pass as female, say); and "gender", "the activity of managing situated conduct in light of normative conceptions of attitudes and activities appropriate for one's sex category" (West and Zimmerman 1987: 127).

From Goffman they draw the idea that gender is some form of "socially scripted dramatization" of idealized gender displays (West and Zimmerman 1987: 130), but concerned, as previously indicated, about Goffman's tendency to separate gender from interaction proper, West and Zimmerman's approach treats "doing gender" as a continuous and inescapable feature of daily social interaction. In an argument that seems to prefigure Butler's later discussion of drag used to highlight the constituted character of gender identity, the authors invoke Harold Garfinkel's study of Agnes, a male-to-female transsexual, in order to explore the connections between sex, sex category, and gender. For West and Zimmerman, “Agnes's case makes visible what culture has made invisible - the accomplishment of gender", because in order to pass as female both before and after her surgery Agnes had through social intercourse to learn how to "do" - to perform - femininity (1987: 131).

Gender performance has a number of characteristics for West and Zimmerman. As noted, it is interactional. Further, because society is organized around sex difference "doing gender is unavoidable" (West and Zimmerman 1987: 137). There is no time, that is, when we cannot do gender. Following Goffman, gender performance is also considered to be dependent on the construction of a series of "institutionalized frameworks" (West and Zimmerman 1987: 137) through which so-called "essential" sex differences are produced and enacted. Moreover, in yet another move that appears to anticipate Butler's contention that sex is an effect of gender, West and Zimmerman note that: "doing gender also renders the social 
arrangements based on sex category accountable as normal and natural, that is, legitimate ways of organizing social life" (1987: 146).

Finally, gender performance is "accountable"; by which they mean that it is open to assessment in terms of whether or not a particular performance conforms to "normative conceptions of masculinity or femininity". Every gender performance is, as they put it, "at the risk of gender assessment" by others (West and Zimmerman 1987: 136, original emphasis). When "we do gender appropriately" we "sustain, reproduce, and legitimate the institutional arrangements" based on sex category. When, however, our gender performance is "inappropriate", then, "we as individuals", rather than the institutional arrangements within which we operate, "may be called to account" (West and Zimmerman 1987: 146). All in all, to West and Zimmerman, therefore, “a person's gender is not simply an aspect of what one is, but more fundamentally, it is something that one does, and does recurrently, in interaction with others" (West and Zimmerman 1987:140, original emphasis).

There is no published evidence that Butler had recourse to the work of West and Zimmerman, yet there are several parallels between their respective works: both see gender as a form of "doing"; both apparently consider gender to naturalize the idea of binary sex; and both note the connections between gender and compulsory heterosexuality, though Butler pursues this insight further. This has led one commentator to speculate that had West and Zimmerman been reading Austin "at the time, they might have called this ["Doing Gender"] an analysis of the performative character of gender" (Connell 2009: 105). But they did not. For all the similarities, however, there are important differences between them.

The theoretical frameworks from which they derive their ideas vary significantly. West and Zimmerman draw primarily from ethnomethodological sources, including most notably Goffman and Garfinkel, but also the writings of Suzanne Kessler and Wendy McKenna (1978). By contrast, Butler works within a theoretical framework influenced by 
Continental philosophy, incorporating ideas from Nietzsche, Foucault, Derrida, amongst others. Moreover, Butler has, more than once, explicitly differentiated her own approach to gender from that of Goffman, on whose work West and Zimmerman expressly build, on the grounds that, in her view, his view of the "self" is opposed to hers. He, she suggests, operates according to some sort of "behaviorist model", where "“expressions"” are said to construct or fashion a social self' (1995: 134; see also 1988), whereas she is concerned with the way that the 'interiority' of the subject is 'a publically regulated and sanctioned form of essence fabrication' (Butler 1988: 528).

So far, we have concentrated on how the twin concepts of performativity and performance have been employed to understand gender identifying two particularly important approaches: an account of gender performativity and an understanding of gender as a form of social performance or interactional "doing". This has revealed some of the diverse ways in which "performance" has been understood--that is, both in theatrical and in ethnomethodological terms--and performativity theorized both as a 'gestural style' (Sedgwick 2003: 6) and, particularly in its deconstructive mode, in more strictly linguistic terms. I suggested at the outset of this article that there are two principal ways in which performativity, specifically, has been relevant for feminist theory. The first, just covered, in terms of gender performativity; the second, in terms of the capacity of "speech", broadly conceived, to harm, wound, degrade, or humiliate its addressees. Within feminism, discussion has centered primarily on pornography as a mode of speech that subordinates women. In the next section, therefore, I examine these feminist debates, starting with the work of Catharine MacKinnon. To set the context for the arguments that follow I return very briefly to Austin's account of performative speech acts in How to Do Things with Words.

\section{Performativity and language}


The focus for Austin is the pragmatics of speech, that is, language as action upon the world. In defining language performative Austin emphasizes that certain form of speech perform the action it describes: as in "I bet" or "I promise". During the course of his deliberations, Austin distinguishes between three types of speech act, a distinction that will become particularly pertinent to feminist discussions. The three sorts of speech act are the locutionary, the illocutionary, and the perlocutionary. A locutionary utterance he defines as "the act of 'saying something"” (Austin 1962: 94, my emphasis), that is, making a meaningful statement. An illocutionary act entails "the performance of an act in saying something" (Austin 1962: 94, my emphasis), a saying that is simultaneously a doing (as in the two examples previously given). Finally, a perlocutionary speech act is an utterance that "will often, or even normally, produce certain consequential effects" on others (Austin 1962: 101, my emphasis), where, in other words, an ensuing effect is produced by saying something (see also Langton 1993; and Loxley 2007). For Austin, simply put, words perform actions and, as a result, a stark differentiation between speech and conduct is untenable.

\section{The performativity of pornography}

In an essay in Feminism Unmodified, MacKinnon puts forward the view that pornography is a "form of "speech" that is also "a kind of act" (1987: 130). Elaborating in Only Words, she notes that pornography is "constructing and performative rather than merely referential or connotative" (MacKinnon 1994: 15). Although MacKinnon develops her account independently of Austin, she acknowledges that, like him, she is advancing an account of “"doing things with words" (1994: 86-87) that undermines the dichotomy between speech and conduct. It is not the content of pornography that concerns her but what pornography enacts; not what it says but what it does. Pornography, MacKinnon declares, equates to "subordinating women through sex" (1994: 20). It is a form of "sexual abuse as speech" 
(1994: 7), which "violates women" (1987: 192), constructs "the social reality of gender, the force behind sexism, the subordination in gender inequality" (1987: 166), and "makes women into objects" (1987: 182). In short, it "makes the world a pornographic place" (1994: 17).

Pornography, for MacKinnon, is not, as it has conventionally been understood, a matter of obscenity, free speech, or morality. Akin to hate-speech it is rather a matter of social inequality, inequality that is "substantially created and enforced - that is done through words and images" (MacKinnon 1994: 9, original emphasis). Pornography, for MacKinnon, is a "constitutive practice" (1987: 173) that produces gender inequality by constructing the abuses suffered by women (she cites rape, battery, sexual harassment, and prostitution) as sex. It "sexualizes" these abuses and "thereby celebrates, promotes, authorizes, and legitimizes them". In so-doing it constructs women "as what men want from sex" (MacKinnon 1987: 171) and, in the process, "institutionalizes the sexuality of male supremacy". 7 As such pornography "eroticizes hierarchy ... [and] sexualizes inequality" (MacKinnon 1987: 172). MacKinnon's contention, however, is that pornography does more than only subordinate women (as if that were not enough).

Drawing from the work of Andrea Dworkin, she contends that it also silences them. As the "speech of men", pornography stops women - those subordinated by its texts and images - from speaking out, rendering their speech "impossible, and where possible, worthless" (MacKinnon 1987: 209, 181). It does so, she speculates, by creating a hostile environment where they are reluctant to protest about the violence against them, for example by reporting rape; pornography produces a context in which, when women do speak, their words are often distrusted; and it silences them by evacuating what they say of meaning, as for instance when a woman's "no" is taken to mean "yes" (see also West 2013). MacKinnon illustrates this by recounting the plight of Anita Hill. Hill alleged that, the-then Supreme Court nominee, Clarence Thomas had sexually harassed her with inappropriate talk, 
including about pornographic films. When Hill testified to this effect during Thomas's Senate confirmation hearings, MacKinnon reports, "much of the response was disbelief, the reaffirmation of the silence of "nothing happened"” "When speech is sex" (1994: 44) MacKinnon notes, women's speech lacks the authority, plausibility, and influence of men's speech.

Responding to claims that MacKinnon's argument is "philosophically incoherent" (Langton 1993: 299), in her paper, "Speech Acts and Unspeakable Acts" (1993), feminist philosopher Rae Langton sets out to assess whether the dual claim that pornography both subordinates women and silences them is philosophically defensible. First, Langton determines whether speech can, in fact, subordinate. Her answer is that it can, provided the speech in question fulfils three criteria: that it ranks a particular group of people as inferior; that it legitimates discriminatory behavior towards them; and that it unjustly deprives them of important powers. By way of illustration Langton considers what happens when a legislator in apartheid Pretoria utters the words: "Blacks are not permitted to vote"” (1993: 302). The effect, she observes, is to deny the right to vote to black South Africans and, as such, to subordinate them.

To count as a subordinating illocution, pornography needs to operate in the same way. It must have what Langton calls, invoking Austin, verdictive and exercitive force. For Austin, verdictives (from verdict) involve giving an estimate, appraisal or reckoning of some kind; they rank. Exercitives involve the "exercising of powers, rights, or influence" (Austin 1962: 151), described by Langton as "actions of ordering, permitting, prohibiting, authorizing, [and] enacting law," they legitimate. As Langton understands them, exercitives also - and this will become relevant later on - "confer powers and rights on people, or deprive people of powers and rights" (1993: 304, my emphasis). Without dwelling too much on the detail here, the point to note about this for Langton is that both exercitives and verdictives are "authoritative" 
- delivered by someone with the appropriate (formal or informal) authority, such as the legislator in Pretoria in her example. In Austinian parlance, this is one of their "felicity" conditions.

Langton concludes from her assessment of MacKinnon's work that pornography is verdictive insofar as it "ranks women as sex objects" (1993: 307). Moreover, it is exercitive in that it "legitimates sexual violence" against women. In these senses, it subordinates. Pornography is, that is, an "illocutionary act of subordination" (Langton 1993: 308, original emphasis). The issue is whether it constitutes authoritative speech. As Langton asks, "“Do its speakers have authority?"” (1993: 311). The answer, she suggests, depends on whether or not pornography is believed to be the utterance of a powerless minority or fringe element of society, or whether as MacKinnon proposes, "pornography's voice is the voice of the ruling power" (Langton 1993: 311). Langton notes simply that this is a question that cannot be "settled from the philosopher's armchair" since it is "empirical" (1993: 312, 329). Nevertheless, she concludes, that on the basis of her evaluation, pornography may indeed subordinate, and that, as such, this claim is philosophically coherent.

What, though, of the contention that pornography silences women? "If speech is action", Langton notes, "then silence is failure to act". As she, rather than MacKinnon construes it, the issue here is whether pornography impedes women from "doing things with their words" (1993: 314). What primarily interests Langton are occasions of "illocutionary disablement", when the right words are spoken, "with the appropriate intention", but the speaker fails to perform the illocutionary act they meant to (1993: 315); when they are somehow prevented or disabled from doing so. If, she surmises, the ability to perform illocutionary acts is a feature of authority or power, the inability to do so is indicative of a lack of authority or power. Does pornography render women's speech acts "unspeakable"? MacKinnon suggests it does. For Langton, the question, is how? What happens, for instance, 
to prevent a woman's "no" "achieving its intended purpose" (Langton 1993: 323); that is to refuse sex?

Langton interprets MacKinnon's claim that pornography silences women to mean that the "felicity conditions for women's speech acts are set by the speech acts of pornography. The words of the pornographer, like the words of the legislator, are "words that set conditions" (Langton 1993: 324, original emphasis), that determine the rules of the linguistic game, and decide what kinds of speech is possible. If pornography works in this way, and again Langton suggests this is only verifiable empirically, then it is authoritative in that it distributes certain linguistic rights and powers. It thus fulfils the third of the criteria specified above: it is a class of illocution that deprives women of the ability to utter certain kinds of speech act. By silencing women, pornography also subordinates them. To Langton the claim that pornography silences women is thus also philosophically defensible.

I want to return briefly to MacKinnon and to the political and legal solutions that she has put forward to deal with pornography. As is well known in feminist and legal circles, MacKinnon, together with Andrea Dworkin, was involved in drafting a number of local antipornography civil rights ordinances in the United States, beginning in 1983. These ordinances define pornography as "a form of discrimination on the basis of sex" that subordinates women "through pictures/and or words", including in ways that dehumanize them, or present them "as sexual objects" who "enjoy humiliation or pain" or "sexual pleasure in rape, incest, or other sexual assault" (MacKinnon 1987: 262 n.1). The purpose of the legislation is not to criminalize the production, sale, or consumption of pornography; rather it is to allow women to sue for damages from pornographers for demonstrable harm done to them by pornographic material and to petition for a future ban on material proven to be harmful. (For a critique of the amendment see Strossen 2000.) 
The fact that MacKinnon champions the legal regulation of pornography is often interpreted through the lens of the first amendment to the US Constitution protecting free speech. ${ }^{8}$ Some critics, most notably Ronald Dworkin (1985), have railed against this, suggesting that for the ordinance to censor pornography as it proposes entails a denial of free speech. Plenty of feminist ink has already been spilt rebutting Ronald Dworkin's case (see Langton 1990, 1993; Hornsby 1993; and West 2003 by way of example), so I do not want to reprise that particular controversy here. I want, instead, to look at an alternative critique, this one advanced by Judith Butler in Excitable Speech (1997).

\section{Hate-speech and the politics of performativity}

One consequence of the line of reasoning presented by MacKinnon, and supported by Langton (amongst others), viz., that pornography silences women is that, in the current pornography-imbued climate, freedom of speech for women may be meaningless. The "purposes of the first amendment, premised upon conditions presumed and promoted by free speech", MacKinnon writes, "do not pertain to women because they are not our condition". This is a condition, she continues, where the "free speech of men silences the free speech of women" (MacKinnon 2009 [1985]: 309). The standard defense of the first amendment is that in a democratic society all viewpoints have the right to be expressed in the "free market place of ideas”. Langton, building on MacKinnon, takes issue with this. Free speech, she surmises, is not about ideas; freedom of speech is "good" when it "enables people to act" (Langton 1993: 328, original emphasis). If women are unable, as Austin put it, to "do things with words", unable to act, then for Langton "that ... is not free speech" (1993: 327).

In Excitable Speech: A Politics of the Performative, Butler (1997) engages the antipornography views of MacKinnon and Langton, as well as the critique of assaultive speech or "words that wound" - proposed by a prominent group of critical race theorists. ${ }^{9}$ She does 
not offer an orthodox free speech defense of pornography, however. Instead she draws her critique from the linguistic approaches of Austin and Derrida. There are several points of connection between Butler and her opponents - the stress on the performativity of language, its centrality to how reality is constructed in inegalitarian and exclusionary ways, and the implied connections between language and subjectivity/identity - but they divide significantly over the best strategy for dealing with wounding words and subordinating speech. What is required to combat "hate-speech" (broadly construed), Butler contends, is not its legal regulation but "talking back", a strategy extrapolated from the idea that, structurally, speech and conduct are always dissociable.

Butler is interested in what it means to claim that language has the capacity to harm. What concerns her is the idea that pornography and hate-speech, in and of themselves, directly and immediately enact the subordination of oppressed groups or persons. She sets out to demonstrate that contra the claims of MacKinnon, Matsuda et al, subordinating speech is perlocutionary rather than illocutionary. For Austin, the two were distinguished by the fact that they operated, as Butler puts it, according to different temporal logics: illocutions requiring the simultaneity of word and deed and perlocutions requiring only that an utterance brings about certain effects as a result. Truncating a longer argument, Butler avers in Derridean fashion that for any performative to succeed (illocutionary or perlocutionary), it has to repeat or recite a "prior and authoritative set of practices" (1997: 51, original emphasis). Every speech act, that is, "exceeds the instance of its utterance" (Butler 1997: 3) and has a past, present, and future iterative context. Pornography and hate-speech are no different. They are citational. They refer to "already existing discursive practices, to already circulating images and encoded trauma" (Passavant and Dean 2001: 377). So, although an individual illocutionary speech-act might enact its effects as it is uttered, its force (its capacity for success) derives from its historicity, from its repetition over time. 
Butler is also concerned about what she terms "the sovereign conceit" (1997: 16) that she alleges is at work in the writings of MacKinnon and the critical race theorists. As she notes of the former, when MacKinnon contends that pornography subordinates women, she "engages a figure of the performative, a figure of sovereign power that governs how a speech act is said to act - as efficacious, unilateral, transitive, generative" (Butler 1997: 74). The allegation is that hate-speech and pornography always attain their harmful, subordinating effects in ways that are, to borrow from Lisa Schwartzman, "immediate and fully predictable" (2002: 423). Again, Butler disagrees: hate speech and pornography do not “always work" (1997: 19). In fact, they can sometimes take on a meaning unlike that intended by their speaker because of the "excitability" of language. In corroboration, she presses into service Austin's differentiation between "felicitous" and "infelicitous" speech acts; that is, speech acts that succeed and those that, for various reasons, fail.

In How to Do Things with Words, Austin lists a number of conditions that are necessary for "happy performatives", as well as the different forms of "misfires" and "abuses" to which they might be prone. Infelicities happen for Austin, according to Derrida, when certain of the conventions that govern the performative are breached; for instance, when the person conducting a marriage service, the purser in Austin's illustration, is legally ineligible to do so (1962: 16). Derrida understands this to mean that Austin construes performative failure as extrinsic to the utterances themselves when, as Derrida has it, they are intrinsic to language. Failure, in other words, is not circumstantial; it is structurally inherent in language as a feature of its iterability. By implication, any term potentially can be wrested from its context and made to connote differently. Butler concurs. This insight is important politically for her because she sees the failure of hate-speech and pornography, as performatives, as the occasion for a critical response to them (Butler 1997: 19). 
To explain how, Butler allies these insights borrowed from Derrida with an interpretation of Louis Althusser's idea of interpellation (when "hailing" - or calling someone constitutes them as a subject), to suggest that noxious speech can be resignified. (Recall that MacKinnon thought that pornography was a means by which women were subjectivated.) Instead of identifying censorship as the solution to sexually and racially assaultive speech, she argues that egregious words can be appropriated and recited to counter their historical associations, and that interlocutors to that speech can refuse its subordinating interpellations by, for instance, taking up a pernicious designation as a self-description. In this way, hate-speech and pornography can be defused of their damaging potential. Changes in meaning of the term "queer" shed light on what she intends here. Once employed as an abusive term to stigmatize and shame those to whom it was addressed, restaged as "part of an affirmative practice" (Butler in Olson and Worsham 2000: 759), it has become an expression celebrating and legitimizing homosexuality (Butler 1993).

One important consequence that follows on from Butler's discussion concerns where the responsibility for hate-speech and pornography lies. In rejecting a legal solution, Butler appears to reject the idea that individuals should be prosecuted for uttering wounding words on the two-fold ground that to do so reduces the widespread structural and institutional dimensions of sexism and racism to individual acts of speech, and ignores the way that any individual utterance is itself always already a recitation of existing racist or sexist language. Not surprisingly, some critics worry that Butler appears to be absolving those deploying hatespeech and pornography of any legal culpability (Mills 2003).

\section{Conclusion}

Feminist theory operates throughout a range of different subject disciplines. The same is also true of the discussions of performativity and performance outlined in this chapter. Butler's 
theorization of gender as performative had a radical impact on feminist theory, in gender and sexuality studies, and in queer theory, with its anti-essentialist characterization of the subject and its particular account of agency (indeed, in 2009 she defined performativity as an “account of agency" [Butler 2009: i]). Indeed in terms of queer theory, Gender Trouble is routinely taken to be one of its originating texts and gender performativity one of its inaugural ideas. ${ }^{10}$ Moreover, gender performativity as a framework has been used as a lens through which to inform readings of diverse cultural texts from the $\mathrm{BBC}$ television series The Office (Tyler and Cohen 2007) to Samuel Beckett's Rockaby (Jones 1998), to explore transgender issues (Chávez 2010), to theorize the performance of sexuality in geographical space (Bell et al., 1994; Valentine 1996), to study gender practices at work (Martin 2001), and to investigate the relation between gender performativity and rape law (Loizidou 1999) amongst many other things. This is not to suggest, of course, that everyone accepted or endorsed Butler's approach. In fact, it has been and continues to be the subject of some controversy.

While its reach in terms of influence is perhaps not as great as Butler's idea of gender performativity, nevertheless West and Zimmerman's proposal that gender is a form of “doing" helped shaped debates in feminist sociology and gender studies. Described as "groundbreaking" by Francine Deutsch (2007: 106), "Doing Gender" was, in 2009, "the most cited article ever published in Gender \& Society" (Jurik and Siemsen 2009: 72). Echoes of West and Zimmerman's work are discernible in studies of female-to-male transsexuals and transgendered persons (Dozier 2005), explorations of the connections between "doing gender" and "doing heteronormativity" when so-called "gender normals" interact with transgender people (Schilt and Westbrook 2009), and investigations of the role of female surgeons (Cassell 1997). There have also been, in response to the critical charge that "doing 
gender" is principally an account of gender conformity, attempts to extend their framework to the notion of "undoing gender" (Deutsch 2007).

The importance of MacKinnon's critique of pornography for feminism cannot be underestimated either. While some feminists rejected the argument that pornography subordinates women in the radical sense deployed by MacKinnon (see, for instance, Cornell 2000), and others challenged MacKinnon's definition of pornography (Strossen 2000), nevertheless her view helped to shift the discussion away from the conventional view that pornography offends to the position that pornography directly (performatively) harms, silences, and oppresses women. One of the most fecund developments in relation to MacKinnon's writings was in the realm of feminist philosophy where numerous authors (Hornsby 1993; Hornsby and Langton 1998; McGowan 2003, 2005; and Maitra 2009), including Langton (1990, 1993), began to explore pornography through Austin's speech act theory, ${ }^{11}$ with some of the more recent texts critically indebted to both MacKinnon and Langton.

It was, in part, the arguments put forth by these two authors that prompted Excitable Speech, which in turn sparked considerable debate in feminist and gender circles. Commentators challenged the accuracy of Butler's readings of MacKinnon, Austin, et al., (Jenkins 2001; Schwartzman, 2002), and registered concern that Butler had underestimated the degree of difficulty of resignifying certain particularly entrenched forms of racial or gender slur (Lloyd, 2007). Additionally, questions were posed about why MacKinnon's own discussion of pornography did not count as an example of resignification for Butler (Jenkins 2001), and about whether Butler's account either adequately addressed the "authority" of hate speech "in the empirical world" (Schwartzman 2002) or the possibility of resistance (Mills 2000). 
Although much more could be said here about the significance of each individual approach, what ought to be clear is that exploration of the two concepts, performance and performativity, significantly transformed feminist theory's apprehension of gender in ways that cannot now be undone.

\section{References}

Assiter, Alison (1996), Enlightened Women: Modernist Feminisms in a Postmodern Age, London and New York: Routledge.

Austin, J. L. (1962), How to Do Things with Words, $2^{\text {nd }}$ edition, Oxford: Oxford University Press.

Beauvoir, Simone de (1983 [1949]), The Second Sex, trans. H. M. Parshley, Harmondsworth: Penguin.

Bell, David, Binnie, Jon, Cream, Julia, and Valentine, Gill (1994), “All hyped up and no place to go", Gender, Place and Culture: A Journal of Feminist Geography, 1 (1): 31 47.

Benhabib, Seyla (1995), "Feminism and Postmodernism: An Uneasy Alliance" in Seyla Benhabib, Judith Butler, Drucilla Cornell, and Nancy Fraser, Feminist Contentions: A Philosophical Exchange, London: Routledge, pp. 17-34.

Brickell, Chris (2003), "Performativity or Performance? Clarifications in the Sociology of Gender”, New Zealand Sociology, 18 (2): 158-78.

Butler, Judith (1986), "Sex and Gender in Simone de Beauvoir's Second Sex", Yale French Studies, 72: 35-49.

Butler, Judith (1988), "Performative Acts and Gender Constitution: An Essay in Phenomenology and Feminist Theory", Theatre Journal 40 (4): 519-31. 
Butler, Judith (1989), “Gendering the Body: Beauvoir's Philosophical Contribution”, in Ann Garry and Marilyn Pearsall (eds), Women, Knowledge, and Reality: Explorations in Feminist Philosophy, pp. 252-62.

Butler, Judith (1990), Gender Trouble: Feminism and the Subversion of Identity, London: Routledge.

Butler, Judith (1993), Bodies that Matter: On the Discursive Limits of "Sex", London: Routledge.

Butler, Judith (1997), Excitable Speech: A Politics of the Performative, London: Routledge. Butler, Judith (2009), "Performativity, Precarity, and Sexual Politics”, Revista de Antropología Iberoamericana, 4(3): i-xiii.

Cassell, Joan (1997), “Doing Gender, Doing Surgery: Women Surgeons in a Man's Profession", Human Organization, 56 (1): 47-52.

Chávez, Karma R. (2010), “Spatializing Gender Performativity: Ecstasy and Possibilities for Livable Life in the Tragic Case of Victoria Arellano", Women's Studies in Communication, 33 (1): 1-15.

Connell, Raewyn (2009), “Accountable Conduct: 'Doing Gender' in Transsexual and Political Retrospect", Gender \& Society 23 (1): 104-11.

Cornell, Drucilla ed. (2000), Feminism and Pornography, Oxford: Oxford University Press. Deegan, Mary Jo (2014), “Goffman on Gender, Sexism, and Feminism: A Summary of Notes on a Conversation with Erving Goffman and My Reflections Then and Now", Symbolic Interaction, 37 (1): 71-86.

Derrida, Jacques (1988 [1972]), “Signature Event Context”, in Limited Inc., Evanston, IL: Northwestern University Press.

Deutsch, Francine M. (2007), “Undoing Gender”, Gender \& Society, 21 (1): 106-127. 
Dozier, Raine (2005), "Beards, Breasts, and Bodies: Doing Sex in a Gendered World", Gender \& Society, 19 (3): 297-316.

Dworkin, Ronald (1985), A Matter of Principle, Cambridge, Mass.: Harvard University Press.

Foucault, Michel (1978), The History of Sexuality, Volume 1: An Introduction, trans. Robert Hurley, Harmondsworth: Penguin.

Goffman, Erving (1959), The Presentation of Self in Everyday Life, Harmondsworth: Penguin.

Goffman, Erving (1974), Frame Analysis: An Essay on the Organization of Experience, Cambridge, Mass.: Harvard University Press.

Goffman, Erving (1976), “Gender Display”, Studies in the Anthropology of Visual Communication, 3 (2): 69-174.

Goffman, Erving (1977), “The Arrangements between the Sexes”, Theory, Culture, \& Society, 4 (3): 301-31.

Hawkes, Gail (1995), “Dressing-Up - Cross Dressing and Sexual Dissonance”, Journal of Gender Studies, 4 (3): 261-70.

Hornsby, Jennifer (1993), “Speech Acts and Pornography”, Women's Philosophy Review, 10: $38-45$.

Hornsby, Jennifer and Langton, Rae (1998), "Free Speech and Illocution” Legal Theory, 4, 21-38.

Jenkins, Fiona (2001), “The Heeding of Differences: On Foreclosure and Openness in a Politics of the Performative", Constellations, 8 (3): 364-75.

Jones, Christine (1998), “Bodily Functions: A Reading of Gender Performativity in Samuel Beckett's Rockaby”, in Jennifer M. Jeffers (ed.), Samuel Beckett: A Casebook, London: Routledge, pp. 179-202. 
Jurik, Nancy C. and Siemsen, Cynthia (2009), “'Doing Gender’ as Canon or Agenda: A Symposium on West and Zimmerman, Gender \& Society, 23 (1): 72-75.

Kessler, Suzanne and McKenna, Wendy (1978), Gender: An Ethnomethodological Approach, New York: Wiley.

Langton, Rae (1990), "Whose right? Ronald Dworkin, women, and pornographers", Philosophy and Public Affairs, 19 (4): 311-59.

Langton, Rae (1993), "Speech Acts and Unspeakable Acts”, Philosophy and Public Affairs, 22 (4): 293-330.

Lloyd, Moya (1999), “The Body”, in Fidelma Ashe et al., Contemporary Social and Political Theory: An Introduction, Buckingham: Open University Press, pp. 111-30.

Lloyd, Moya (2007), Judith Butler: From Norms to Politics, Cambridge: Polity.

Lloyd, Moya (2011), "From Linguistic Performativity to Social Performance: The Development of a Concept”, in Gerard Delanty and Stephen P. Turner (eds), Routledge International Handbook of Contemporary Social and Political Theory, London: Routledge, pp. 270-79

Loizidou, Elena (1999), “The Trouble with Rape: Gender Matters and Legal Transformations", Feminist Legal Studies, 7 (3): 275-97.

Loxley, James (2007), Performativity, London: Routledge.

MacKinnon, Catharine A. (1987), Feminism Unmodified: Discourses on Life and Law, Cambridge, Mass.: Harvard University Press.

MacKinnon, Catharine A. (1994), Only Words, London: HarperCollins Publishers. MacKinnon, Catharine A. (2009 [1987]), "From Pornography, Civil Rights, and Speech", in Lewis Vaughn (ed.), Doing Ethics: Moral Reasoning and Contemporary Issues, $2^{\text {nd }}$ edition, New York: W.W. Norton \& Co., pp. 299-311.

Maitra, Ishani (2009), “Silencing Speech”, Canadian Journal of Philosophy, 39 (2): 309-38. 
Martin, Biddy (1992), "Sexual Practice and Changing Lesbian Identities”, in Michèle Barrett and Anne Phillips (eds), Destablising Theory: Contemporary Feminist Debates, Cambridge: Polity, pp. 93-119.

Martin, Patricia Yancey (2003), “'Said and Done’ Versus 'Saying and Doing': Gendering Practices, Practicing Gender at Work", Gender \& Society, 17 (3): 342-66.

Matsuda, Mari J., Lawrence III, Charles R., Delgado, Richard, and Williams Crenshaw, Kimberlè (1993), Words that Wound: Critical Race Theory, Assaultive Speech, and the First Amendment, Boulder: Westview Press.

McGowan, Mary Kate (2003), "Conversational Exercitives and the Force of Pornography”, Philosophy and Public Affairs, 31 (2): 155-89.

McGowan, Mary Kathryn (2005), “On Pornography: MacKinnon, Speech Acts and 'False' Construction", Hypatia, 20 (3): 23-49.

Mills, Catherine (2000), "Efficacy and Vulnerability: Judith Butler on Reiteration and Resistance", Australian Feminist Studies, 15 (32): 265-79.

Mills, Catherine (2003), "Contesting the Political: Foucault and Butler on Power and Resistance”, The Journal of Political Philosophy, 11(3): 253-72.

Newton, Esther (1972), Mother Camp: Female Impersonators in America, Chicago: Chicago University Press.

Nicholson, Linda (1994), “Interpreting Gender”, Signs: Journal of Women in Culture and Society, 20 (1): 79-105.

Oakley, Ann (2005 [1972]), “The Difference between Sex and Gender”, in The Ann Oakley Reader: Gender, Women and Social Science, Bristol: The Policy Press, pp. 7-12.

Olson, Gary A. and Worsham, Lynn (2000), “Changing the Subject: Judith Butler's Politics of Radical Resignification” [an interview], jac, 20 (4): 727-765.

Passavant, Paul and Dean, Jodi (2001), "Laws and Societies", Constellations, 8 (3): 376-89. 
Probyn, Elspeth (1995), "Lesbians in Space: Gender, Sex, and the Structure of Missing", Gender, Place and Culture: A Journal of Feminist Geography, 2 (1): 77-84.

Rich, Adrienne (1980), “Compulsory Heterosexuality and Lesbian Existence”, Signs: Journal of Women in Culture and Society, 5 (4): 531-60.

Rothenberg, Molly Anne, and Joseph Valente (1997), "Performative Chic: The Fantasy of a Performative Politics", College Literature, 24 (1): 295-304.

Schilt, Kristen and Westbrook, Laurel (2009), “Doing Gender, Doing Heteronormativity: 'Gender Normals', Transgender People, and the Social Maintenance of Heterosexuality", Gender \& Society, 23 (4): 440-64.

Schwartzman, Lisa H. (2002), "Hate Speech, Illocution, and Social Context: A Critique of Judith Butler", Journal of Social Philosophy, 33 (3): 421-41.

Sedgwick, Eve Kosofsky (2003), Touching Feeling: Affect, Pedagogy, Performativity, Durham and London: Duke University Press.

Smith, Greg (2011), “Erving Goffman”, in George Ritzer and Jeffrey Stepnisky (eds), The Wiley-Blackwell Companion to Major Social Theorists: Volume II Contemporary Social Theorists, Oxford: Wiley Blackwell, pp. 125-54.

Strossen, Nadine (2000), Defending Pornography: Free Speech, Sex, and the Fight for Women's Rights, New York: New York University Press.

Tyler, Melissa and Cohen, Laurie (2007), “Management in/as Comic Relief: Queer Theory and Gender Performativity in The Office", Gender, Work, and Organization, 15 (2): $113-132$.

Valentine, Gill (1996), “(Re)negotiating the 'Heterosexual Street': Lesbian productions of space”, in Nancy Duncan (ed.), BodySpace: destabilising geographies of gender and sexuality, London: Routledge, pp. 146-55. 
Walker, Julia A. (2003), 'Why Performance? Why Now? Textuality and the Rearticulation of Human Presence", The Yale Journal of Criticism, 16 (1): 149-175.

Weir, Allison (1996), Sacrificial Logics: Feminist Theory and the Critique of Identity, London: Routledge.

West, Candace (1996), “Goffman in Feminist Perspective”, Sociological Perspectives, 39 (3): 353-69.

West, Caroline (2003), “A Free Speech Argument against Pornography”, Canadian Journal of Philosophy, 33 (3): 391-422.

West, Caroline (2013), "Pornography and Censorship", The Stanford Encyclopedia of Philosophy (Fall 2013 Edition), Edward N. Zalta (ed.), http://plato.stanford.edu/archives/fall2013/entries/pornography-censorship/ (last accessed 13 October 2014).

West, Candace and Zimmerman, Don H. (1987), “Doing Gender”, Gender \& Society, 1 (2): $125-51$.

Wittig, Monique (1981), “One is Not Born a Woman”, Feminist Issues, 1 (2): 47-54.

\footnotetext{
${ }^{1}$ For general discussion of the concept of performativity in philosophy, social and political theory, including the work of J.L. Austin, Jacques Derrida, and Judith Butler, see Loxley 2007 and Lloyd 2011.

${ }^{2}$ For further discussion of Butler's account of sex and gender, see Lloyd 2007.

${ }^{3}$ In her 1988 article Butler also makes explicit reference to texts in performance studies by Bruce Wilshire, and Richard Schechner, as well as Turner.

${ }^{4}$ She does, however, recognize that there is a difference between theatrical performances of gender and gender performances in non-theatrical contexts, where the risks attaching to the performance may be much higher (see 1988: 527).
} 
${ }^{5}$ The index gives a second reference to Turner (allegedly on page 2); however, this appears to be a proofing error because there is no mention of Turner at that point in the text.

${ }^{6}$ For West and Zimmerman, conventional understandings do not address the difficulties sometimes attendant on ascribing biological sex to a body or to the apparent fixity of gender from an early age. Additionally, they often do not recognize that the relation of biology to culture is more complex than often assumed.

${ }^{7}$ MacKinnon's discussion also extends to children, though for the purposes of this article I have focused on how it relates to women.

${ }^{8}$ In fact her reference point is the Fourteenth Amendment - the equal protection amendment.

${ }^{9}$ One of Butler's targets is the volume, Words that Wound, written by critical legal scholars Mari Matsuda, Charles R. Lawrence III, Richard Delgado, and Kimberlè Williams Crenshaw (1993).

${ }^{10}$ The other academic routinely identified as inaugurating the field of queer studies is Eve Kosofsky Sedgwick. Sedgwick develops an idea of 'queer performativity' out of the work of Austin and explores its operation in literary texts, including the work of Henry James (see, for example, Sedgwick 2003).

${ }^{11}$ As we have seen MacKinnon understands pornography to be performative. but as noted, she does not deploy Austin's technical vocabulary, terms like 'illocutionary' or 'perlocutionary', to do so, yet as Langton notes her account rests on the use, in particular, of illocutionary verbs like 'promote', 'authorize', 'legitimate' (Langton 1993: 307) to expose what pornography does. 